\title{
Physical Properties of Boards Manufactured with Hygrothermally Treated Tepa (Laureliopsis Philippiana Looser) Particles
}

\section{Fizikalna svojstva ploča proizvedenih od hidrotermički obrađenog iverja drva tepe (Laureliopsis philippiana Looser)}

\author{
Original scientific paper • Izvorni znanstveni rad \\ Received-prispjelo: 29. 12. 2015. \\ Accepted-prihvaćeno: 5. 5. 2016. \\ UDK: $630 * 861.232 ; 630 * 812.22 ; 630 * 812.23 ; 630 * 847.26$ \\ doi:10.5552/drind.2016.1547
}

\begin{abstract}
Three layer particleboards were manufactured using hygrothermally treated and untreated Laureliopsis philippiana (tepa) particles with urea-formaldehyde (UF) resin. Hygrothermal treatment consisted of autoclaving particles at $150^{\circ} \mathrm{C}$ for $90 \mathrm{~min}(430 \mathrm{kPa})$ in a steam saturated atmosphere. Density, moisture content, swelling and water absorption were determined. Equilibrium moisture, dimensional variation in length and thickness, as well as length and thickness coefficients per every $1 \%$ change in board equilibrium moisture were also determined after acclimatization at different relative air humidity conditions $\left(20^{\circ} \mathrm{C} ; 40,50,60,70,80\right.$ and $90 \%$ $R A H)$. There were significant differences between particleboards made from control and treated particles. Boards manufactured with treated particles showed a reduction in moisture content, swelling and water absorption. Dimensional stability analysis in response to relative air humidity (RAH) showed that the hygrothermal treatment causes a reduction in equilibrium moisture, a decrease in length and thickness dimensional variation, likewise a reduction in length and thickness swelling coefficients.
\end{abstract}

Key words: Particleboard, hygrothermal treatment, Laureliopsis philippiana, physical properties, dimensional stability

SAŽETAK • Za potrebe ovog ispitivanja troslojne su ploče iverice proizvedene od neobrađenoga i hidrotermički obrađenog iverja drva tepe (Laureliopsis philippiana) primjenom urea-formaldehidnog (UF) ljepila. Hidrotermička obrada sastojala se od zagrijavanja iverja pri $150{ }^{\circ} \mathrm{C}$ tijekom 90 minuta u atmosferi zasićenoj

\footnotetext{
${ }^{1}$ Author is professor at School of Forest Engineering, Faculty of Environmental Sciences, State Technical University of Quevedo, QuevedoEcuador. ${ }^{2}$ Author is professor at Department of Forest Management and Environment, Faculty of Forestry, University of Concepción, Concepción-Chile. ${ }^{3}$ Author is professor at the Forest Products Laboratory, Faculty of Forestry and Natural Resources Sciences, Austral University of Chile, Valdivia-Chile.

Autor je profesor Fakulteta znanosti o okolišu, Državno tehničko sveučilište u Quevedu, Quevedo, Ekvador. ${ }^{2}$ Autor je profesor Odjela za gospodarenje šumama i okolišem, Šumarski fakultet, Sveučilište u Concepciónu, Concepción, Čile. ${ }^{3}$ Autor je profesor Laboratorija za šumske proizvode, Fakultet znanosti o šumama i prirodnim resursima, Južno sveučilište u Čileu, Valdivia-Čile.
} 
vodenom parom (pri tlaku $430 \mathrm{kPa}$ ). Pritom su određeni gustoća, sadržaj vode, bubrenje i upijanje vode ploča iverica. Ravnotežni sadržaj vode, dimenzijske varijacije u smjeru duljine i debljine, kao i koeficijenti promjene duljine $i$ debljine ploče iverice zbog promjene ravnotežnog sadržaja vode za 1 \% određeni su nakon aklimatizacije pri različitim relativnim vlažnostima zraka $\left(20{ }^{\circ} \mathrm{C}\right.$; 40, 50, 60, 70, 80 i $90 \%$ RAH). Utvrđene su velike razlike među pločama ivericama izrađenima od neobrađenoga i hidrotermički obrađenog iverja. Naime, ploče proizvedene od hidrotermički obrađenog iverja imale su manji sadržaj vode, manje bubrenje i upijale su manje vode. Analiza dimenzijske stabilnosti ploča iverica u ovisnosti o promjeni relativne vlažnosti zraka (RAH) pokazala je da je hidrotermičkom obradom iverja prouzročeno smanjenje ravnotežnog sadržaja vode, smanjene su dimenzijske varijacije ploča u smjeru duljine i debljine, odnosno smanjeni su koeficijenti bubrenja u smjeru duljine i debljine ploče.

Ključne riječi: ploča iverica, hidrotermička obrada, Laureliopsis philippiana, fizikalna svojstva, dimenzijska stabilnost

\section{INTRODUCTION}

\section{UVOD}

High temperature heat treatment (thermo-modification) is known to improve dimensional stability of wood as well as its resistance to rot (Niemz et al., 2010). Thermal modification drives structural and chemical changes in wood constituents, which may significantly alter their properties when compared to non-treated wood (Arnold, 2010).

\subsection{Acidity}

1.1. Kiselost

Density and chemical composition are among wood properties and characteristics that most affect particleboard quality. Chemical composition of wood has an effect in particular stages of the process (drying, gluing and setting). Chemical composition also affects the properties of the boards, since the presence of extractable compounds determines de $\mathrm{pH}$ value, and they can delay, hasten or inhibit the setting process (Poblete, 2001). Chemical reactions that occur during setting of the adhesives follow an optimum course with a specific $\mathrm{pH}$ range for each type of adhesive, and any variation will have an effect on the bonding properties among particles. L. philippiana wood exhibits high $\mathrm{pH}$ values (5.7 to 7.4), which is not favorable for the production of boards using acidic setting adhesives (UF) (Poblete, 2001). Wood pH decreases after high temperature thermal treatment (Niemz et al., 2010). Thermal treatments cause decomposition of hemicelluloses and acidify the wood (Poblete, 1983), which could favor setting of the UF and improve physical properties of the board.

\subsection{Effect of thermal treatment on physica} properties of boards

1.2. Utjecaj toplinske obrade iverja na fizikalna svojstva ploča

Tomek (1966) states that thermal treatment of the particles decreases adsorption properties, resulting in a decrease in thickness swelling of $45 \%$ to $50 \%$ in particleboards manufactured with treated particles and UF. Boonstra et al. (2006) indicate that hygrothermolysis has a positive effect on thickness swelling, and hence thermal treatment of the wood before the manufacturing process could improve the dimensional stability of the particleboards.

\subsection{Effect of thermal treatment on board} dimensional changes

1.3. Utjecaj toplinske obrade iverja na dimenzijsku stabilnost ploča

Thermal treatment reduces wood contraction and swelling, improving its dimensional stability (Cao et al., 2012). The difference between equilibrium moisture content of treated and non-treated wood remains when the air humidity changes (Edvarsden and Sandland, 1999). Most of the defects of the particleboards during their performance are related to thickness swelling, which is considerably greater than in other wood products of comparable density. This instability is caused by the incorporation of compressive tensions that are released when the moisture content increases (Suchsland and Enlow, 1968). A treatment with steam before manufacturing could cause a partial hydrolysis in the hemicelluloses, which increases compressibility of the wood, and significantly reduces the increment in internal tension during board pressing, making this process an effective method to produce dimensionally stable boards (Hsu et al., 1988). In this type of treatment, a pressure increment of 200 to $1000 \mathrm{kPa}$ causes important increases in the dimensional stability (Giebeler, 1983).

\subsection{Objectives}

1.4. Ciljevi

The main objective of this study was to determine the effect of a hygrothermal treatment in a steam saturated atmosphere on L. philippiana particles and its impact on the physical properties of three layer particleboards. Specific objectives were to determine the changes in moisture content, swelling and water absorption after 2 and 24 hours, as well as to determine the equilibrium moisture and the dimensional stability after acclimatizing at different RAHs $\left(20{ }^{\circ} \mathrm{C} ; 40,50\right.$, $60,70,80$ and $90 \%$ ).

\section{MATERIALS AND METHODS} 2. MATERIJAL I METODE

\subsection{Particles production and hygrothermal} treatment

2.1. Proizvodnja iverja i njegova hidrotermička obrada

L. philippiana wood was harvested in the XIV Region de Los Ríos at the Andean Mountain in Chile. The wood was made into shavings and then, particles 
were obtained by using a Pallmann PZ2 mill. A quantity of the particles was treated in autoclave at $150{ }^{\circ} \mathrm{C}$ for $90 \mathrm{~min}$ at the pressure of $430 \mathrm{kPa}$, in a steam saturated atmosphere. At the end of the treatment, the particles were allowed to acclimatize to ambient conditions.

\subsection{Drying of particles \\ 2.2. Sušenje iverja}

Hygrothermally treated and non-treated particles were subjected to a drying process, in a Heraeus particle dryer with air circulation at $70{ }^{\circ} \mathrm{C}$ until a moisture content of $4 \%$ was reached.

\subsection{Board manufacturing}

\subsection{Proizvodnja ploča}

Hygrothermally treated and untreated L. philippiana particles were employed. As adhesive, UF (50\% solid) produced by Georgia Pacific Corp. with a molar ratio of 1:1.22 was applied. Particleboards with nominal densities of $600,625,650,675$ and $700 \mathrm{~kg} \cdot \mathrm{m}^{-3}$, with dimensions of $53 \times 53 \mathrm{~cm}$ and $15 \mathrm{~mm}$ thickness were produced. The adhesive was applied at $8 \%$ loading (dry basis) by spraying in a Drais FSP-80 blender. Pressing was conducted in a Bürkle LA-160 press at a temperature of $180^{\circ} \mathrm{C}$ for $180 \mathrm{~s}$. The initial maximum pressure used was $3 \mathrm{~N} \cdot \mathrm{mm}^{-2}$ for $30 \mathrm{~s}$, followed by a lower pressure of $1.5 \mathrm{~N} \cdot \mathrm{mm}^{-2}$ for $150 \mathrm{~s}$. Two boards were produced for each nominal density, a total of 10 boards with non-treated particles and 10 boards with treated particles. The particle ratio was $70 \%$ in the inner layer and $30 \%$ in the outer layer.

\subsection{Physical properties of the boards}

2.4. Fizikalna svojstva ploča

Density (EN 323, 1993), moisture content (EN 322, 1993), swelling (EN 317, 1993) and water absorption (ASTM D 1037, 2012 in test specimens EN 317, 1993) were determined. The number of test specimens by treatment for physical properties (moisture content, swelling and water absorption) was 100. Density was determined for every test specimen.

\subsection{Dimensional stability of the boards}

2.5. Dimenzijska stabilnost ploča

4 test specimens $200 \mathrm{~mm}$ long by $20 \mathrm{~mm}$ wide of each board were prepared. Test specimens were acclimatized in a Heraeus Vötsch HPZ 50/ S - DV chamber at a constant temperature of $20^{\circ} \mathrm{C}$ and a RAH of 40 , 50, 60, 70, 80 and $90 \%$. Equilibrium moisture (EN 322 , 1993), longitudinal and thickness dimensional variations (EN 318, 2002), and dimensional variations per every $1 \%$ equilibrium moisture variation $(\mathrm{Niemz}$ and Poblete, 1996) were determined.

\subsection{Statistical analysis}

\subsection{Statistička analiza}

A simple linear regression analysis was conducted, correlating physical properties to density of the respective test specimen. Additionally, an analysis of variance was conducted with a $99 \%$ confidence interval $(p<0.01)$ (statistical program $\mathrm{R})$, to determine differences among averages of properties. For the study of dimensional stability, average values (from $40 \%$ to $90 \%$ of RAH) of equilibrium moisture of the board were correlated with the averages values of longitudinal and thickness swelling.

\section{RESULTS AND DISCUSSION} 3. REZULTATI I RASPRAVA

\subsection{Board physical properties}

3.1. Fizikalna svojstva ploča

Table 1 shows the averages, standard deviation, coefficient of variation and $p$ value, according to the analysis of variance for boards manufactured with hygrothermally treated and untreated particles.

There are significant differences $(p<0.01)$ among physical properties of boards manufactured with hygrothermally treated and untreated particles. Particleboards

Table 1 Analysis of variance of means of physical properties of L. philippiana boards manufactured with hygrothermally treated and untreated particles

Tablica 1. Analiza varijance srednjih vrijednosti fizikalnih svojstava ploča proizvedenih od neobrađenoga i hidrotermički obrađenog iverja

\begin{tabular}{|c|c|c|c|c|c|c|c|}
\hline \multirow{3}{*}{$\begin{array}{l}\text { Physical property } \\
\text { Fizikalna svojstva }\end{array}$} & \multicolumn{7}{|c|}{ Analysis of variance / Analiza varijance } \\
\hline & \multicolumn{3}{|c|}{$\begin{array}{c}\text { Untreated } \\
\text { Neobrađeno iverje }\end{array}$} & \multicolumn{3}{|c|}{$\begin{array}{c}\text { Hygrothermally treated } \\
\text { Hidrotermički obrađeno iverje }\end{array}$} & \multirow{2}{*}{$\begin{array}{c}p \text {-value } \\
p \text {-vrijednost }\end{array}$} \\
\hline & $\begin{array}{l}\bar{x} \\
\%\end{array}$ & $\begin{array}{l}s d \\
\%\end{array}$ & $\begin{array}{l}c v \\
\%\end{array}$ & $\begin{array}{l}\bar{x} \\
\%\end{array}$ & $\begin{array}{l}s d \\
\%\end{array}$ & $\begin{array}{l}c v \\
\%\end{array}$ & \\
\hline $\begin{array}{l}\text { Moisture content / sadržaj vode } \\
\left(20^{\circ} \mathrm{C} / 65 \% \mathrm{RAH}\right)\end{array}$ & 9.9 & 0.67 & 6.76 & 8.0 & 0.25 & 3.12 & $0.000^{*}$ \\
\hline $\begin{array}{l}\text { Swelling after } 2 \text { hours } \\
\text { bubrenje nakon } 2 \text { sata }\end{array}$ & 34.8 & 2.90 & 8.34 & 8.9 & 0.89 & 10.00 & $0.000^{*}$ \\
\hline $\begin{array}{l}\text { Swelling after } 24 \text { hours } \\
\text { bubrenje nakon } 24 \text { sata }\end{array}$ & 47.1 & 3.97 & 8.43 & 14.2 & 1.32 & 9.23 & $0.000^{*}$ \\
\hline $\begin{array}{l}\text { Water absorption after } 2 \text { hours } \\
\text { upijanje vode nakon } 2 \text { sata }\end{array}$ & 97.4 & 10.78 & 11.07 & 60.9 & 9.95 & 16.36 & $0.000^{*}$ \\
\hline $\begin{array}{l}\text { Water absorption after } 24 \text { hours } \\
\text { upijanje vode nakon } 24 \text { sata }\end{array}$ & 115.7 & 9.87 & 8.53 & 75.5 & 9.47 & 12.54 & $0.000^{*}$ \\
\hline
\end{tabular}

$\bar{x}$ - Average value / srednja vrijednost, sd-standard deviation / standardna devijacija, cv-coefficient of variation / koeficijent varijacije,

* - significance at $p<0.01$ / signifikantno pri $p<0,01$. 
manufactured with hygrothermally treated L. philippiana particles showed better physical properties.

\subsubsection{Board moisture content $\left(20^{\circ} \mathrm{C}, 65 \% \mathrm{RAH}\right)$}

3.1.1. Sadržaj vode u pločama (pri $20^{\circ} \mathrm{C}, 65 \% \mathrm{RAH}$ )

Boards manufactured with treated particles had lower moisture content than boards manufactured with untreated particles. The reduction in moisture was from $9.9 \%$ in boards with untreated particles to $8.0 \%$ in boards with treated particles. Similar results are reported by other authors (Mendes et al. 2013). The moisture reduction in boards manufactured with treated particles is related to chemical changes within the wood. Studying the effect of hygrothermal treatment on L. philippiana particles, Crespo et al. (2013) determined a decrease in wettability, a significant increase in extractable hydrophobic compounds and a reduction in $\mathrm{pH}$ value, changes caused by chemical alterations within the wood, particularly of hemicelluloses. Other authors state that an increase in the relative crystalline cellulose may also have an influence, with hydroxyl groups poorly accessible to water molecules, and the crosslinking of the lignin chain, hindering access to free hydroxyl groups (Burmester, 1975; Tjeerdsma et al., 1998).

\subsubsection{Swelling and water absorption after 2 and 24 hours}

3.1.2. Bubrenje i upijanje vode nakon $2 \mathrm{~h}$ i nakon $24 \mathrm{~h}$

Swelling and water absorption after 2 and 24 hours of immersion were lower in boards manufac- tured with treated particles (Table 1). A decrease in swelling was recorded from $34.8 \%$ to $8.9 \%$ and from $47.1 \%$ to $14.2 \%$ after 2 and 24 hours, respectively. A decrease of water absorption from $97.4 \%$ to $60.9 \%$ after 2 hours and from $115.7 \%$ to $75.5 \%$ after 24 hours was determined. This trend is in agreement with results reported by Tomek (1966), Boonstra et al. (2006) and Poblete and Peredo (1990). The increase in the amount of extractable hydrophobic compounds and the reduction in wettability in treated L. philippiana particles determined by Crespo et al. (2013), could explain the changes in the physical properties. Crespo et al. (2013) also reported a significant reduction in the $\mathrm{pH}$ value (6.7 to 4.8) and an increase in acidity, which favors the adhesive setting process (UF), contributing to the improvement in physical properties. The linear regression analysis showed no correlation between density, moisture content and swelling after 2 and 24 hours. Water absorption values and their relationship to density after 2 and 24 hours are presented in Figure 1.

Regardless of the treatment, the board density increase caused a decrease in L. philippiana board water absorption (Figure 1). This is due to the fact that boards of less density have more space within their structure, allowing a greater amount of water to penetrate. Linear regression analysis reported a high correlation and significance at $p<0.01$ between density and water absorption after 2 hours and after 24 hours (Figure 1). This indicates that water absorption decreases as board density increases.
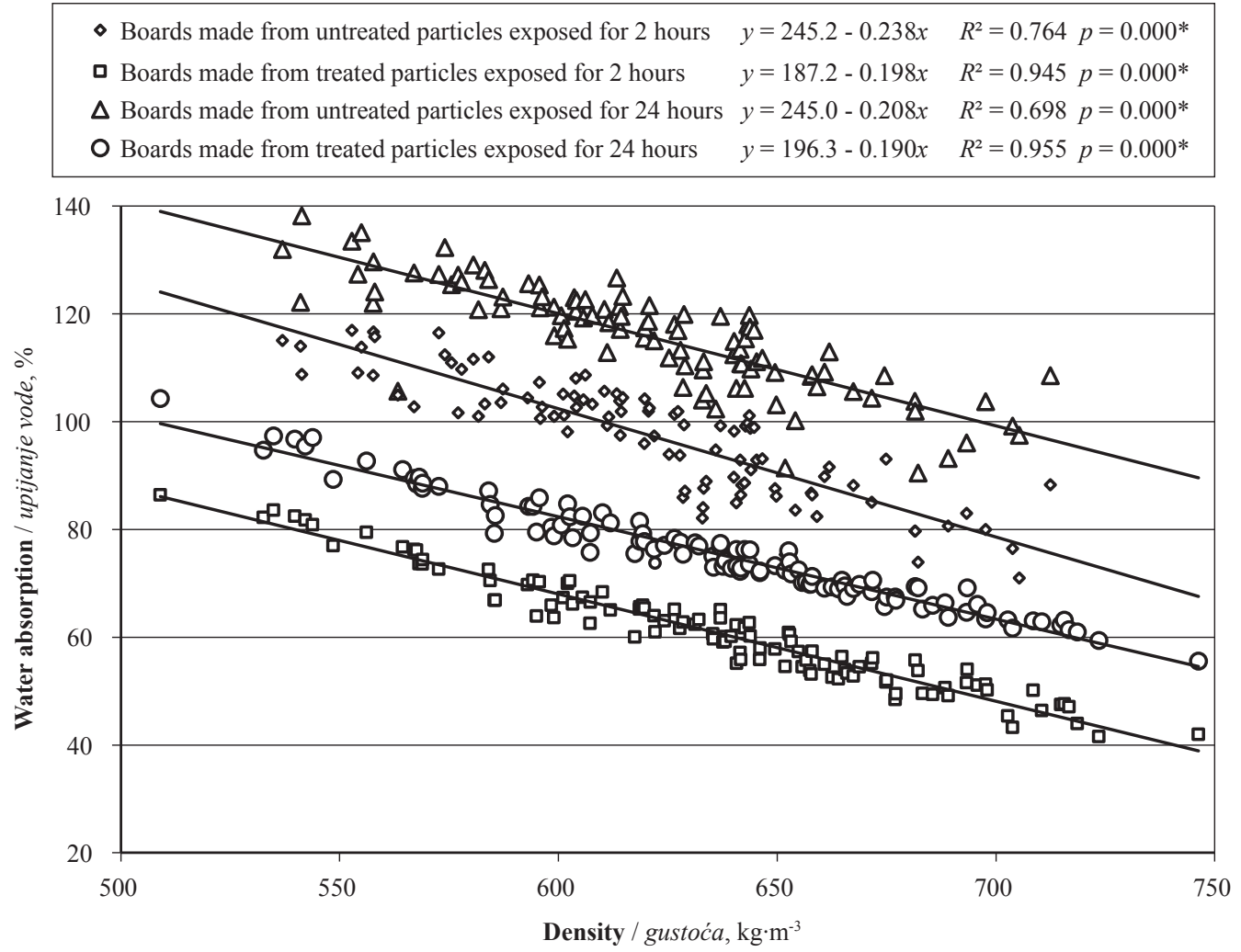

Figure 1 Effect of density on water absorption (2 and 24 hours) of L. philippiana boards manufactured using untreated and hygrothermally treated particles

Slika 1. Utjecaj gustoće ploče proizvedene od neobrađenoga i hidrotermički obrađenog iverja drva tepe na upijanje vode (nakon $2 \mathrm{~h}$ i nakon $24 \mathrm{~h}$ ) 


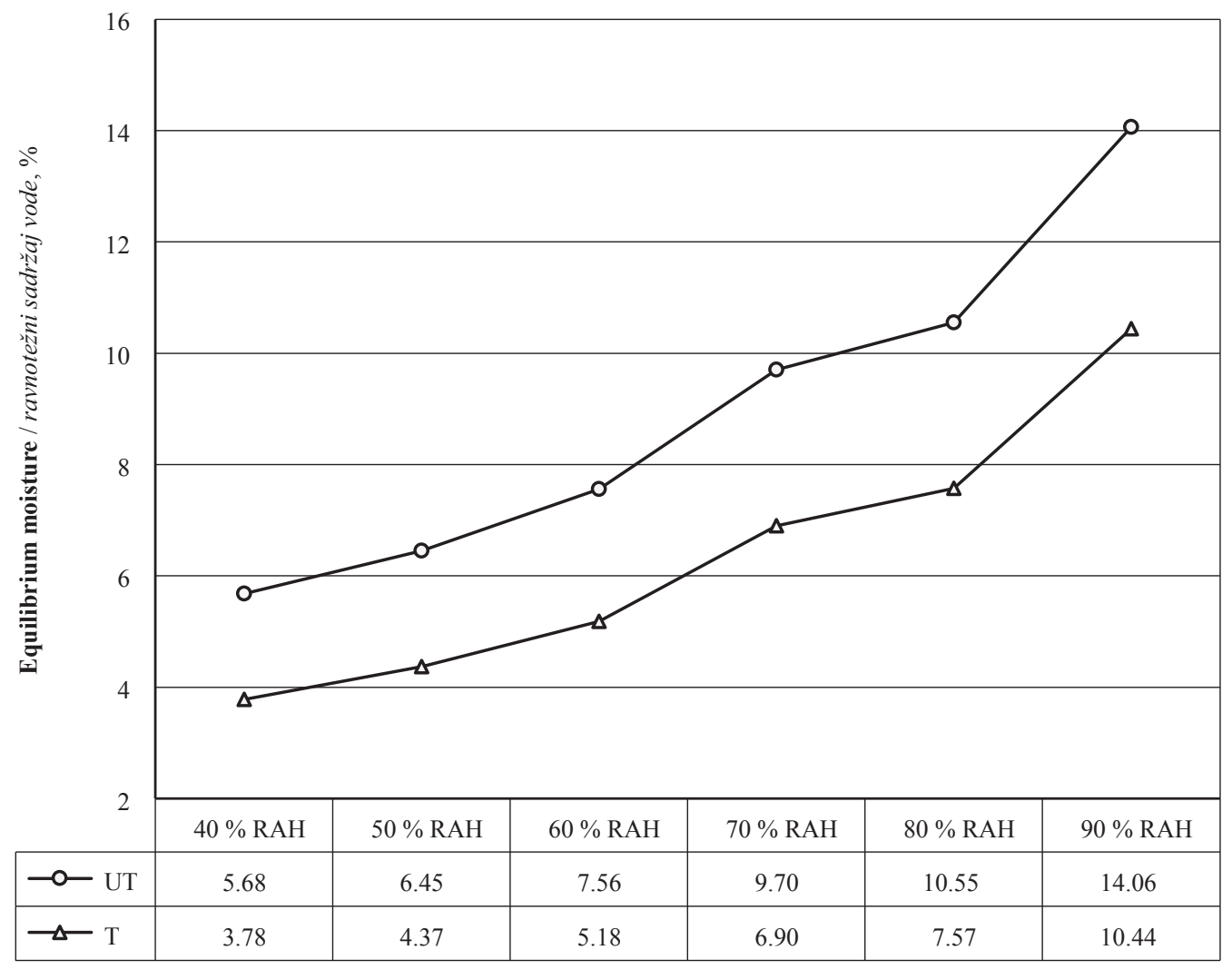

Figure 2 Equilibrium moisture values at different RAH conditions and $20{ }^{\circ} \mathrm{C}$ in boards manufactured using hygrothermally treated (T) and untreated (UT) L. philippiana particles

Slika 2. Vrijednosti ravnotežnog sadržaja vode ploča proizvedenih od neobrađenoga i hidrotermički obrađenog iverja drva tepe pri različitoj vlažnosti zraka i temperaturi $20^{\circ} \mathrm{C}$

\subsection{Boards dimensional stability}

\subsection{Dimenzijska stabilnost ploča}

3.2.1 Equilibrium moisture with changes in RAH

3.2.1. Ravnotežni sadržaj vode u pločama u ovisnosti o vlažnosti zraka

Equilibrium moisture of boards at different RAH conditions at $20^{\circ} \mathrm{C}$ are presented in Figure 2.

A significant reduction in equilibrium moisture content was registered in boards manufactured with hygrothermally treated particles. When RAH was increased from $40 \%$ to $90 \%$, in boards manufactured with untreated particles, an increase of the equilibrium moisture from $5.68 \%$ to $14.06 \%$ was recorded, whereas the boards manufactured with treated particles showed an increase from $3.78 \%$ to $10.44 \%$. Popper et al. (2005) studied the effect of thermal treatment of solid wood on the equilibrium moisture and swelling, with RAHs between $11 \%$ and $93 \%$ at a constant temperature of $22{ }^{\circ} \mathrm{C}$. These researchers registered a reduction in both properties, indicating that the changes in the chemical composition would be the cause for the reduction. Crespo et al. (2013) stated that the hygrothermal treatment increases the amount of hydrophobic compounds in hygrothermally treated L. philippiana particles and also reported an acidification of treated particles, which has a positive effect on the UF setting, since $L$. philippiana is a species with $\mathrm{pH}$ values close to neutral. Both changes in the chemical composition of the particles are reflected in a decrease of equilibrium moisture of boards.

\subsubsection{Dimensional variation in length and thickness}

3.2.2. Varijacije dimenzija ploča u smjeru duljine i debljine

Figures 3 and 4 show the dimensional variation (length and thickness) in boards at different RAH conditions. Boards manufactured with hygrothermally treated particles, regardless of the RAH, presented less dimensional variation in length and thickness than boards manufactured with untreated particles. The difference between treated and untreated particles increases proportionally to increments in RAH. It should also be noted that from $60 \%$ RAH on, significant and increasing differences in dimensional variation in length and thickness of hygrothermally treated and untreated boards were observed. At $90 \% \mathrm{RAH}$, the greatest differences in length and thickness swelling were present. The length dimensional variations at $90 \%$ RAH decrease from $0.254 \%$ in boards with untreated particles to $0.166 \%$ in boards with treated particles. In the case of thickness swelling, the decrease was from $9.081 \%$ in boards with untreated particles to $4.656 \%$ in boards with treated particles. The improvement in dimensional stability recorded in boards manufactured with hygrothermally treated particles is in agreement with the results reported by Hsu et al. (1988), who stated that the linear expansion and thickness swelling of particleboards glued with UF, caused by variation in moisture content, were substantially reduced by hygrothermal treatment of 


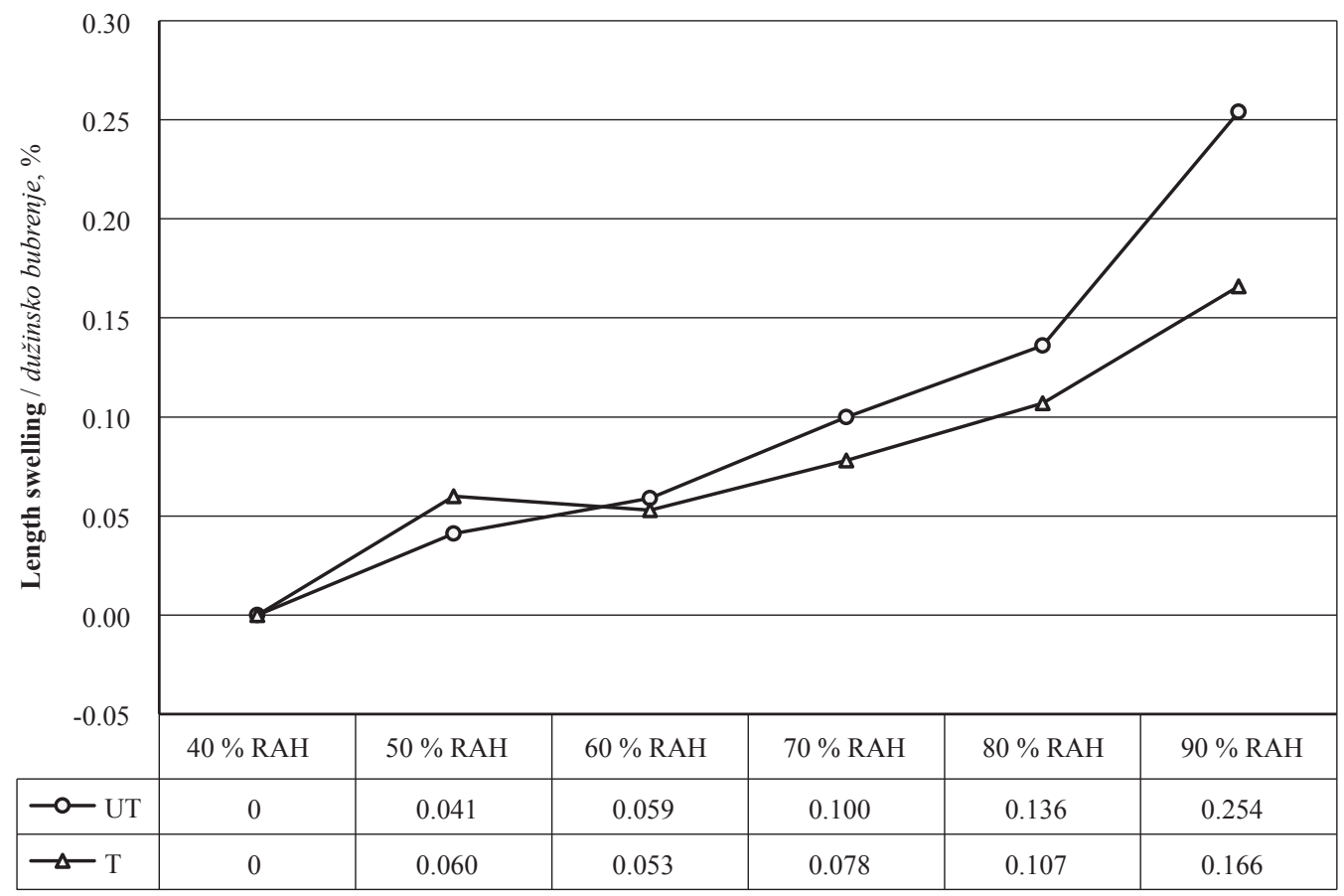

Figure 3 Dimensional variation in length at different RAH conditions in boards manufactured using untreated (UT) and hygrothermally treated (T) L. philippiana particles

Slika 3. Varijacije dimenzija u smjeru duljine ploča proizvedenih od neobrađenoga (UT) i hidrotermički obrađenog (T) iverja drva tepe pri različitoj vlažnosti zraka i temperaturi $20^{\circ} \mathrm{C}$

the particles. Hsu et al. (1988) reported that thickness swelling was reduced from $12.1 \%$ to $3.6 \%$ and linear expansion from $0.48 \%$ to $0.24 \%$. In the case of boards manufactured with hygrothermally treated particles and UF, the improvement of the dimensional stability could be related to the increase in extractable hydrophobic compounds by hemicelluloses degrada- tion, reported in hygrothermally treated L. philippiana particles by Crespo et al. (2013). As reported, the increase in acidity in hygrothermally treated L. philippiana particles also contributed to an improvement in board dimensional stability, since this chemical change allows for better setting of the UF, improving the particle-adhesive-particle association.

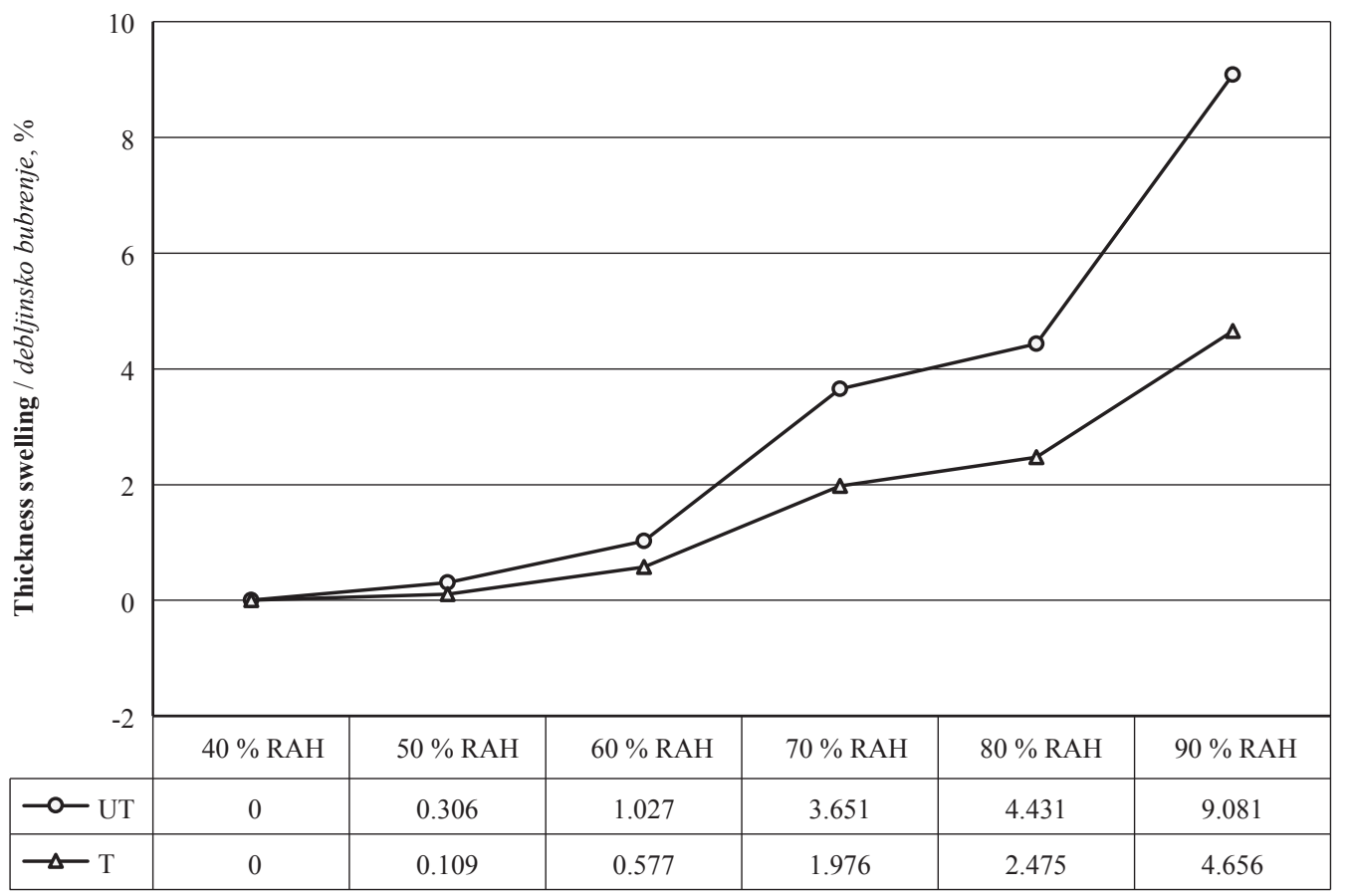

Figure 4 Dimensional variation in thickness at different RAH conditions in boards manufactured using untreated (UT) and hygrothermally treated (T) L. philippiana particles

Slika 4. Varijacije dimenzija u smjeru debljine ploča proizvedenih od neobrađenoga (UT) i hidrotermički obrađenog (T) iverja drva tepe pri različitoj vlažnosti zraka i temperaturi $20^{\circ} \mathrm{C}$ 
Table 2 First degree equations and determination coefficients of dimensional variation in thickness and length and different RAH conditions in boards manufactured using hygrothermally treated and untreated L. philippiana particles.

Tablica 2. Jednadžbe prvog stupnja i koeficijenti determinacije ovisnosti dimenzijskih varijacija ploča u smjeru duljine i debljine o vlažnosti zraka za ploče proizvedene od neobrađenoga i hidrotermički obrađenog iverja drva tepe

\begin{tabular}{|c|c|c|c|}
\hline Property / Svojstvo & Condition / Uvjeti & Equation / Jednadžba & $\boldsymbol{R}^{2}$ \\
\hline Thickness swelling & Untreated / neobrađeno & $T S=0.028 R A H-0.159$ & 0.981 \\
\cline { 2 - 5 } debljinsko bubrenje & Hygrothermally treated / hidrotermički obrađeno & $T S=0.021 R A H-0.061$ & 0.918 \\
\hline Length swelling & Untreated / neobrađeno & $L S=1.104 R A H-6.858$ & 0.985 \\
\cline { 2 - 5 } bubrenje u duljinu & Hygrothermally treated / hidrotermički obrađeno & $L S=0.724 R A H-2.986$ & 0.993 \\
\hline
\end{tabular}

TS - Thickness swelling / debljinsko bubrenje, LS: Length swelling / bubrenje u duljinu, RAH - Relative air humidity / relativna vlažnost zraka.

In Table 2, the first degree equations are defined, as well as the determination coefficient for the relationship between the average equilibrium moisture and thickness and length swelling. According to the regression analysis, there is a high correlation between equilibrium moisture, length and thickness swelling at different RAH. The obtained equations can predict board dimensional variations. Similar results were obtained by Niemz and Poblete (1996).

\subsection{Dimensional variations in relation to a $1 \%$} change in equilibrium moisture of the boards 4.3. Varijacije dimenzija ploča s obzirom na promjenu ravnotežnog sadržaja vode u pločama za $1 \%$

Length and thickness swelling coefficients per every $1 \%$ equilibrium moisture change in boards were obtained as a quotient of length and thickness swelling at $90 \% \mathrm{RAH}$, which was then divided by the result of the subtraction of equilibrium moisture at $90 \% \mathrm{RAH}$ and equilibrium moisture at $40 \% \mathrm{RAH}$. The length and thickness swelling coefficients for every $1 \%$ change in equilibrium moisture of the boards were lower in boards manufactured with hygrothermally treated particles. The decrease of boards manufactured with non-treated particles compared to boards manufactured with treated particles was of $0.030 \%$ to $0.025 \%$ for longitudinal swelling, and $1.083 \%$ to $0.700 \%$ for thickness swelling. The values obtained in the current study for swelling coefficient of the boards are similar to the values reported by Niemz and Poblete (1996) of boards manufactured with thermally untreated particles. The reduction in the thickness swelling coefficient caused by the hygrothermal treatment is in agreement with results reported by Suchsland and Enlow (1968), who stated that the specific thickness swelling (percent swelling per $1 \%$ change in moisture content) during exposure to $90 \%$ relative humidity conditions decreases in thermally treated 3-layer particleboards.

\section{CONCLUSIONS}

5. ZAKLJUČAK

Hygrothermal treatment of L. philippiana particles has positive effects on physical properties and dimensional changes of boards. A decrease in equilibrium moisture content, swelling and water absorption after a 2 and 24 hours immersion was determined in boards manufactured with hygrothermally treated particles. In this research, trials results from dimensional stability showed that equilibrium moisture, longitudinal and thickness swelling are reduced in boards manufactured with hygrothermally treated particles. Consequently, longitudinal and thickness swelling coefficients are also reduced for every $1 \%$ change in equilibrium moisture of the boards. It can be concluded that hygrothermal treatment of L. philippiana particles at $150{ }^{\circ} \mathrm{C}$ for $90 \mathrm{~min}$ at the pressure of $430 \mathrm{kPa}$, is an alternative to improve dimensional stability of boards manufactured for this species.

\section{Acknowledgements - Zahvala}

This study was supported by a scholarship from the Comisión Nacional de Investigación Científica y Tecnológica (CONICYT) from Chile, and by the Secretaría de Educación Superior, Ciencia, Tecnología e Innovación (SENESCYT) from Ecuador.

\section{REFERENCES}

\section{LITERATURA}

1. Arnold, M., 2010: Effect of moisture on the bending properties of thermally modified beech and spruce. Journal of Materials Science, 45 (3): 669-680.

http://dx.doi.org/10.1007/s10853-009-3984-8.

2. ASTM D 1037. 2012: Standard Test Methods for Evaluating Properties of Wood-Base Fiber and Particle Panel Materials. West Conshohocken, United States, 30 p.

3. Boonstra, M.; Pizzi, A.; Zomers, F.; Ohlmeyer, M.; Paul, W., 2006: The effects of a two stage heat treatment process on the properties of particleboard. Holz als Roh- und Werkstoff, 64 (2): 157-164.

http://dx.doi.org/10.1007/s00107-005-0055-y.

4. Burmester, A., 1975: Zur Dimensionsstabilisierung von Holz. Holz als Roh- und Werkstoff, 33 (9): 333-335. http://dx.doi.org/10.1007/BF02612789.

5. Cao, Y.; Lu, J.; Huang, R.; Jiang, J., 2012: Increased dimensional stability of Chinese fir through steam-heat treatment. European Journal of Wood and Wood Products, 70 (4): 441-444. http://dx.doi.org/10.1007/s00107-011-0570-y.

6. Crespo, R.; Torres, M.; Valenzuela, L.; Poblete, H., 2013: Propiedades químicas, color y humectabilidad de partículas de Laureliopsis philippiana (tepa) con y sin tratamiento térmico. Maderas. Ciencia y tecnología, 15 (3): 337-348. http://dx.doi.org/10.4067/S0718-221X2013005000026.

7. Edvarsden, K.; Sandland, K., 1999: Increased drying temperature - Its influence on the dimensional stability of wood. Holz als Roh- und Werkstoff, 57 (3): 207-209. http://dx.doi.org/10.1007/s001070050042.

8. EN 317. 1993: Particleboards and fibreboards. Determination of swelling in thickness after immersion in water. 
European Committee for Standardization. Brussels, Belgium, $5 \mathrm{p}$.

9. EN 318. 2002: Wood based panels-Determination of the dimensional changes associated with changes in relative humidity. European Committee for Standardization. Brussels, Belgium, 8 p.

10. EN 322. 1993: Wood-based panels. Determination of moisture content. European Committee for Standardization. Brussels, Belgium, 4 p.

11. EN 323. 1993: Wood based panels. Determination of density. European Committee for Standardization. Brussels, Belgium, 5 p.

12. Giebeler, E., 1983: Dimensionsstabilisierung von Holz durch eine Feuchte/Wärme/Druck-Behandlung. Holz als Roh- und Werkstoff, 41 (3): 87-94.

http://dx.doi.org/10.1007/BF02608498

13. Hsu, W.; Schwald, W.; Schwald, J.; Shields, J., 1988: Chemical and physical changes required for producing dimensionally stable wood-based composites. Part 1: Steam pretreatment. Wood Science and Technology, 22 (3): 281-289. http://dx.doi.org/10.1007/BF00386023.

14. Mendes, R.; Júnior, G.; de Almeida, N.; Surdi, P.; Barbeiro, I., 2013: Effect of thermal treatment on properties of OSB panels. Wood Science and Technology, 47 (2): 243-256. http://dx.doi.org/10.1007/s00226-012-0494-7.

15. Niemz, P.; Poblete, H., 1996: Untersuchungen zur Dimensionsstabilität von mitteldichten Faserplatten (MDF) und Spanplatten. Holz als Roh- und Werkstoff, 54 (2): 141-144. http://dx.doi.org/10.1007/s001070050154.

16. Niemz, P.; Hofmann, T.; Rétfalvi, T., 2010: Investigation of chemical changes in the structure of thermally modified Wood. Maderas. Ciencia y tecnología, 12 (2): 69-78 http://dx.doi.org/10.4067/SO718-221X2010000200002.
17. Poblete, H. 1983: Veränderungen in Holzspänen Während der Trocknung und des Pressens zu Holzspanplatten. Dissertation zur Doktorgrades. Georg August Universität zu Göttingen, $157 \mathrm{p}$.

18. Poblete, H., 2001: Tableros de Partículas. Universidad Austral de Chile. Facultad de Ciencias Forestales. Editorial El Kultrún. Valdivia, Chile, 177 p.

19. Poblete, H.; Peredo, M., 1990: Tableros de desechos del debobinado de especies chilenas. Bosque, 11 (2): 45-58. http://dx.doi.org/10.4206/bosque.1990.v11n2-05

20. Popper, R.; Niemz, P.; Eberle, G., 2005: Untersuchungen zum Sorptions- und Quellungsverhalten von thermisch behandeltem Holz. Holz als Roh- und Werkstoff, 63 (2): 135-148. http://dx.doi.org/10.1007/s00107-004-0554-2.

21. Suchsland, O.; Enlow, R., 1968: Heat Treatment of Exterior Particleboard. Forest Products Journal, 18 (8): 24-28.

22. Tjeerdsma, B.; Boonstra, M.; Pizzi, A.; Tekely, P.; Militz, H., 1998: Characterisation of thermally modified wood: Molecular reasons for wood performance improvement. Holz als Roh- und Werkstoff, 56 (3): 149-153. http://dx. doi.org/10.1007/s001070050287.

23. Tomek, A., 1966: Die Heißvergütung von Holzspänen, ein neues Verfahren zum Hydrophobieren von Spanplatten. Holztechnologie, 7 (3): 157-160.

\section{Corresponding address:}

Prof. HERNÁN POBLETE, Dr.

Universidad Austral de Chile

VALVIDIA, CHILE

e-mail: hernanpoblete@uach.cl 